\title{
Proces zakupów na rynku B2B, ukierunkowany na zrównoważony rozwój Rola wytycznych ISO 20400
}

\author{
Mgr Jakub Brzeziński \\ Uniwersytet Łódzki, Wydział Zarządzania, Katedra Logistyki \\ Dr Agata Rudnicka-Reichel \\ Uniwersytet Łódzki, Wydział Zarządzania, Katedra Logistyki
}

\section{Wprowadzenie}

Proces zakupów ma kluczowe znaczenie dla osiągnięcia celu biznesowego. Praktyki zakupowe pozwalają bowiem na wybór dostawców spełniających określone wymagania czy sformułowanie zakresu wzajemnych zobowiązań umożliwiających budowanie długich i korzystnych relacji. Koncepcja zrównoważonego rozwoju na stałe weszła do zestawu zagadnień związanych z zarządzaniem przedsiębiorstwami. Firmy dostrzegają potrzebę reorientacji swoich strategii i doskonalenia procesów biznesowych pod kątem włączania kryteriów społecznych i środowiskowych. Proces zakupów jest strategiczny dla prawidłowego funkcjonowania organizacji. Od jego skuteczności zależy to, jaki produkt otrzyma klient i czy możliwe będzie wywiązanie się ze złożonej na rynku deklaracji. Wszystkie bez wyjątku firmy potrzebują tego procesu do realizacji swoich celów biznesowych. W ostatnich latach coraz więcej uwagi poświęca się usprawnianiu procesu zakupów i zaopatrzenia. Poszukiwane są rozwiązania, które zapewnią stabilność i pewność dostaw, przy jednoczesnej dbałości o spełnienie oczekiwań odbiorcy, związanych ze zrównoważonym rozwojem. Celem opracowania jest przedstawienie problematyki zrównoważonych zakupów. Punkt wyjścia to omówienie wytycznych ISO 20400, które są jednym ze sposobów na przejście procesu integracji zrównoważonego rozwoju w wybranym aspekcie biznesowym. Artykuł ma charakter teoretyczny. Zamierzeniem autorów było odniesienie się do jednego z ważniejszych wyzwań dla biznesu, jakim jest zrównoważony rozwój, i umiejscowienie go w konkretnym procesie biznesowym. 


\section{Miejsce zakupów w tańcuchu dostaw}

W niniejszym opracowaniu autorzy odnoszą się do zakupów na poziomie procesu biznesowego, stanowiącego sekwencję działań prowadzącą do zakupu produktów lub usług - od powstania potrzeby zakupowej do realizacji zapłaty dostawcy. Mając na uwadze pełnioną przez zakupy rolę, ujmują ich istotę jako pozyskiwanie zasobów potrzebnych w dalszych etapach tworzenia wartości w łańcuchu dostaw ${ }^{1}$. Zarówno łańcuchy dostaw, jak i tworzące je przedsiębiorstwa funkcjonują w systemie gospodarczym, dążąc do realizacji swoich celów, pośród których wyróżnia się tworzenie wartości rynkowej. Zakupy mogą wspierać realizację tego celu na cztery sposoby: poprzez wpływ na zmniejszenie kosztów operacyjnych, wzrost przychodów oraz redukcję aktywów obrotowych i trwałych, co z kolei przekłada się na redukcję kapitału obrotowego netto oraz kapitału stałego ${ }^{2}$. Szczególną rolę zakupów należy dostrzec w możliwości redukcji kosztów w całym cyklu życia produktów, włączając dostawców do procesu już na etapie projektowania i rozwoju produktu 3 .Zdaniem Ocickiej dobre praktyki zakupowe, takie jak: trafne określenie specyfikacji, standaryzacja, staranna selekcja dostawców, profesjonalne zarządzanie kontraktami i relacjami z dostawcami, prowadzą do redukcji kosztów nabycia i dostarczenia materiałów wysokiej jakości . Są to elementy zarządzania zakupami, rozumianego jako zarządzanie zewnętrznymi zasobami przedsiębiorstwa w taki sposób, aby zapotrzebowanie na produkty, usługi, umiejętności i zasoby wiedzy, niezbędne do funkcjonowania organizacji oraz do zarządzania jej czynnościami podstawowymi i pomocniczymi, było zapewnione na jak najlepszych warunkach ${ }^{5}$. Zarządzanie zakupami jest także postrzegane jako potencjalne źródło budowania przewagi konkurencyjnej przedsiębiorstwa ${ }^{6}$. W tym miejscu należy podkreślić, że przewagę konkurencyjną budują zarówno zasoby wewnętrzne, jak i zewnętrzne, w tym dostawcy, od których firmy kupują oprócz produktów i usług także wiedzę i umiejętności7.

1 Por. K. Lysons, B. Farrington, Purchasing and Supply Chain Management, Pearson Education, Harlow 2006, s. 3-5.

2 M. Christopher, L. Ryals, Supply chain strategy: its impact on shareholder value, „International Journal of Logistics Management" 1999, vol. 10, no. 1, s. 4.

3 B. Ocicka, Rola zakupów w działalności przedsiębiorstw, Wydawnictwo Naukowe PWN, Warszawa 2019, s. 46.

4 Tamże.

5 A.J. van Weele, Purchasing and Supply Chain Management. Analysis, Strategy, Planning and Practice, Cengage Learning, Andover 2010, s. 7.

6 A. Tchokogue, J. Nollet, J. Robineau, Supply's strategic contribution: An empirical reality, „Journal of Purchasing and Supply Chain Management” 2017, vol. 23, issue 2, s. 122.

7 K. Rutkowski, Zakupy w biznesie - potrzeba strategicznej reorientacji, „Kwartalnik Nauk o Przedsiębiorstwie" 2013, nr 4, s. 38. 
Współpraca z dostawcami, obok współpracy z klientami i współpracy wewnętrznej z partnerami różnych szczebli, jest jedną z trzech głównych płaszczyzn współpracy w ramach łańcucha dostaw, prezentowaną w literaturze przedmiotu ${ }^{8}$. Zacieśniając relacje z partnerami pierwszego rzędu, przedsiębiorstwa poszukują możliwości poprawy swojej pozycji konkurencyjnej. Z punktu widzenia zakupów jest to o tyle istotne, iż pozwala angażować dostawców już na wczesnych etapach pracy nad daną ofertą, a więc pośrednio wpływać na wykorzystywane przez nich materiały i metody produkcji. Bliska współpraca z dostawcami prowadzi również do ich współodpowiedzialności za tworzony produkt, co skłania do podejmowania większych wysiłków w celu jego doskonalenia. Bardziej postępowe organizacje zdają sobie sprawę z faktu, iż decyzje zakupowe są bodźcem, który mocniej motywuje dostawców do szybszych zmian niż cokolwiek innego w ramach organizacji ${ }^{9}$. Wpływ zakupów na zrównoważony rozwój staje się tym samym znaczny, ponieważ umożliwia oddziaływanie na całą bazę dostawców.

Przedsiębiorstwa dostrzegające istotną rolę zakupów w ramach własnej działalności rozwijają koncepcję strategicznego zarządzania zakupami (strategic purchasing). Kluczowe czynniki tego podejścia określili Carter i Narasimhan, wskazując na umocowanie funkcji zakupowej w strukturze organizacyjnej i wsparcie najwyższej kadry zarządzającej, interakcje z innymi funkcjami biznesowymi oraz dostawcami w łańcuchu dostaw, a także kompetencje osób zarządzających zakupami ${ }^{10}$. Strategiczne zarządzanie zakupami definiuje się w tym kontekście jako proces planowania, wdrażania, oceny i kontrolowania strategicznych i operacyjnych decyzji zakupowych, ukierunkowujący wszystkie działania funkcji zakupowej na wykorzystanie możliwości rynkowych w sposób spójny ze zdolnościami przedsiębiorstw do osiągania celów długoterminowych ${ }^{11}$. Jak zauważa Mena, zrównoważony rozwój powinien być integralnym elementem strategicznego zarządzania zakupami na poszczególnych etapach procesu.

Akcentując tematykę strategicznej funkcji zakupów, szczególnie w kontekście prezentowanej w dalszej części artykułu normy ISO 20400, należy zdefiniować strategię zakupową i jej powiązanie z polityką zakupową przedsiębiorstwa. Strategia zakupowa określa wzorce dla podejmowania decyzji odnoszących się

8 B.B. Flynn, B. Huo, X. Zhao, The impact of supply chain integration on performance: a contingency and configuration approach, „Journal of Operations Management” 2010, vol. 28, no. 1 , s. 58-71.

9 C. Mena, Sustainable Procurement, [w:] C. Mena, R. van Hoyek, M. Christopher, Leading procurement strategy. Driving value through the supply chain, Kogan Page, Croydon 2014, s. 173.

10 J.R. Carter, R. Narasimhan, Is purchasing really strategic?, „International Journal of Purchasing and Materials Management" 1996, vol. 32, no. 4, s. 22-24.

11 A.S. Carr, L.R. Smeltzer, An empirically based operational definition of strategic purchasing, „European Journal of Purchasing and Supply Management” 1997, vol. 3, no. 4, s. 201. 
do pozyskania materiałów i usług potrzebnych do wsparcia działań zgodnych ze strategią przedsiębiorstwa ${ }^{12}$. Precyzuje więc priorytety zakupów, określa sposób i podejście do zaangażowania w relacje $z$ innymi funkcjami biznesowymi i dostawcami, zasoby i zdolności, jakie są wymagane, by osiągnąć rezultaty według określonych planów, sposób zarządzania oraz podział zadań i odpowiedzialności ${ }^{13}$.

W odróżnieniu od strategii zakupowej polityka zakupowa jest zbiorem zasad, których powinni przestrzegać pracownicy funkcji zakupowej w swoich decyzjach i działaniach mających na celu realizację celów strategicznych ${ }^{14}$. Definiuje więc ona główny kierunek rozwoju zakupów oraz ułatwia ich postrzeganie i komunikowanie interesariuszom w spójny sposób. Polityka zakupowa jest w tym kontekście jednym z elementów umożliwiających rozwój i realizację strategii zakupowej15.

\section{Wtączanie zrównoważonego rozwoju do procesu zakupów}

Potrzeba uwzględnienia kwestii związanych ze zrównoważonym rozwojem w procesach logistycznych to temat, który nabiera coraz większego znaczenia ${ }^{16}$. Firmy dbające o wymiar pozaekonomiczny mają świadomość, że wartość produktu determinują wszystkie ogniwa łańcucha dostaw, w tym w szczególności dostawcy odpowiedzialni za dostarczenie surowców i komponentów. Przykłady z ostatnich lat, w których największe korporacje światowe, takie jak Nestlé17, Apple czy Google ${ }^{18}$, musiały mierzyć się z problemem łamania praw człowieka w swoich łańcuchach

12 Ch.A. Watts, K.Y. Kim, Ch.K. Hahn, Linking Purchasing to Corporate Competitive Strategy, „International Journal of Purchasing and Materials Management” 1992, vol. 31, issue 1, s. 2-8.

13 B. Ocicka, Rola zakupów..., s. 144.

14 R.M. Monczka i wsp., Purchasing and Supply Chain, Management, South-Western Cengage Learning, Andover 2010, s. 136.

15 P. Cousins i wsp., Strategic Supply Management. Principles, Theories and Practice, Pearson Education, Harlow 2008, s. 93.

16 J. Quariguasi Frota Neto i wsp., Designing and evaluating sustainable logistics networks, ,International Journal of Production Economics” 2008, vol. 111, issue 2, s. 195-208; D.B. Grant, A. Trautrims, C.Y. Wong, Sustainable logistics and supply chain management: principles and practices for sustainable operations and management, Kogan Page Publishers, New York 2017.

17 Nestlé oskarżone o zatrudnianie dzieci. Czy w Polsce problem też występuje?, https://www .pulshr.pl/prawo-pracy/nestl-oskarzone-o-zatrudnianie-dzieci-czy-w-polsce-problem-tez -wystepuje,30942.html (dostęp: 5.02.2020).

18 Śmierć dzieci w kopalniach kobaltu. Pozwane Apple, Google, Dell i Tesla, https://www.national -geographic.pl/aktualnosci/smierc-dzieci-w-kopalniach-kobaltu-pozwy-dla-apple-google -dell-i-tesla (dostęp: 5.02.2020). 
dostaw, tylko potwierdziły konieczność zwracania szczególnej uwagi na procesy logistyczne, w tym zakupy. Rośnie świadomość wyzwań środowiskowych i związanych z tym działań mających na celu ograniczanie lub przeciwdziałanie pogłębianiu się negatywnych zjawisk. Stąd konieczność przyjrzenia się partnerom biznesowym i oceny tego, w jakim stopniu dostarczane przez nich surowce oraz sam sposób dostawy spełniają ustalone kryteria. Przedsiębiorstwa zaczęły myśleć o swoich decyzjach w kategoriach ryzyka. Czy wejście we współpracę z danym dostawcą wiąże się z dodatkowym ryzykiem, na przykład reputacyjnym? Wszystko to spowodowało większe zainteresowanie koncepcjami, które starają się porządkować złożone relacje i nadawać ramy współpracy uwzględniające kryteria pozaekonomiczne ${ }^{19}$.

Pośród metod ułatwiających wdrożenie zasad zrównoważonego rozwoju w praktykach zakupowych przedsiębiorstw wyróżnić można podejście określane w anglojęzycznej literaturze przedmiotu jako supply chain governance ${ }^{20}$. Angażując swoich partnerów w proces zakupowy, przedsiębiorstwa będące liderami łańcucha dostaw powinny dysponować „mechanizmami” umożliwiającymi im kierowanie rozwojem współpracy w pożądanym kierunku. Do „mechanizmów” tych można zaliczyć kontrakty z dostawcami, standardy czy kodeksy postępowania (codes of conduct). Narzędzia te mogą być wprost wykorzystane przez przedsiębiorstwa do zapewnienia stosownych wymagań, odnoszących się do zrównoważonego rozwoju uczestników łańcucha dostaw.

Podstawowym sposobem wpływania na dostawców, występującym przy każdej transakcji na rynku B2B, jest umowa handlowa. Zawierając kontrakt, kontrahenci mogą dowolnie kształtować wiążący ich stosunek prawny, dopóki nie będzie on sprzeczny z właściwością stosunku, przepisami prawa lub zasadami współżycia społecznego ${ }^{21}$. Przedsiębiorcy mają zatem możliwość umieszczania w umowach klauzul odnoszących się do środowiskowych czy też społecznych elementów wpływających na równoważony rozwój. Odnosi się to również do zamówień publicznych, które - poprzez inkorporowanie przepisów Unii Europejskiej - coraz częściej zawierane są z wykorzystaniem takich klauzul ${ }^{22}$. Przykładem zapisów społecznych mogą być zastrzeżenia zamówień

19 D. Kumar, Z. Rahman, Sustainability adoption through buyer supplier relationship across supply chain: A literature review and conceptual framework, „International Strategic Management Review" 2015, vol. 3, issues 1-2, s. 110-127.

20 Por. M. Boström i wsp., Sustainable and responsible supply chain governance: challenges and opportunities, „Journal of Cleaner Production” 2015, no. 107, s. 1-7; A. Ghosh, J. Fedorowicz, The role of trust in supply chain governance, „Business Process Management Journal” 2008, vol. 14(4), s. 453-470.

21 Art. 353 (1) Ustawy z dnia 23 kwietnia 1964 r. - Kodeks cywilny (Dz.U. z 1964 r. Nr 16, poz. 93 z późn. zm.).

22 Komisja Europejska opracowała i udostępniła publikację Ekologiczne zakupy! Podręcznik dotyczący zielonych zamówień publicznych, https://ec.europa.eu/environment/gpp/pdf/ha ndbook_2016_pl.pdf (dostęp: 5.02.2020). 
dla podmiotów, u których ponad 50 procent zatrudnionych pracowników stanowią osoby niepełnosprawne, czy też wymogi dotyczące zatrudnienia na podstawie umowy o pracę. W odniesieniu do środowiska klauzule mogą obejmować wprowadzanie energooszczędnych rozwiązań (np. w zakresie oświetlenia, termoizolacji budynków, oszczędzania wody), rozwiązań mających wpływ między innymi na zmniejszenie emisji dwutlenku węgla, osłabianie efektu cieplarnianego (np. kupowanie energooszczędnych komputerów czy samochodów) czy też na zmniejszanie ilości produkowanych odpadów (np. zamawianie opakowań podlegających recyklingowi lub rozkładających się w sposób naturalny) ${ }^{23}$. Kontrakty mogą również zwierać odniesienia do zewnętrznych źródeł norm, takich jak międzynarodowe lub krajowe standardy, kodeksy dobrych praktyk, załączniki stanowiące ustalenia korporacyjne.

Drugim narzędziem ułatwiającym wdrażanie zrównoważonego rozwoju w procesie zakupowym mogą być wspomniane kodeksy postępowania dostawców (codes of conduct). Przedsiębiorstwa dostrzegające znaczenie zakupów i zarządzania relacjami z dostawcami, często opracowują kodeksy, będące wyznacznikiem i drogowskazem dla swoich partnerów handlowych (np. Toyota code of conduct, Walmart standards for suppliers). Dokumenty te mogą dotyczyć różnych kwestii: warunków technicznych, wymagań środowiskowych czy standardów etycznych ${ }^{24}$.

Kolejnym wspomnianym już sposobem wyrażania oczekiwań dotyczących zrównoważonego rozwoju są ponadprzemysłowe standardy niemające charakteru prawa powszechnego. Międzynarodowe fora specjalistów i powołane do tego celu organizacje rządowe, jak również te z sektora NGO, zajmują się standaryzacją i normalizacją poszczególnych aspektów działalności gospodarczej. Kluczową rolę na arenie globalnej odgrywa w tym zakresie Międzynarodowa Organizacja Normalizacyjna (International Organization for Standardization - ISO). Istnieje wiele standardów odnoszących się w swoich postanowieniach do zrównoważonego rozwoju. Pośród nich można wyróżnić normy z rodziny ISO 14000, normę ISO 26000, PAS 2050, standardy Fairtrade czy Rainforest Alliance. Pierwszą normą poświęconą zrównoważonemu rozwojowi w odniesieniu do procesu zakupowego jest powołana do życia w 2017 roku norma ISO 20400: 2017 Sustainable Procurement ${ }^{25}$, będąca przedmiotem rozważań dalszej części artykułu.

23 Klauzule społeczne i środowiskowe w zamówieniach publicznych, https://www.swietokrz yskie.pro/klauzule-spoleczne-i-srodowiskowe-w-zamowieniach-publicznych/ (dostęp: 5.02.2020).

24 A. Rudnicka, Codes of conduct and codes of ethics as tools used to support the idea of social responsibility in supply chains, „Prace Naukowe Uniwersytetu Ekonomicznego we Wrocławiu" 2017, nr 464, s. 91-100.

25 ISO 20400: 2017 Sustainable Procurement - Guidance ma status Polskiej Normy PN-ISO 20400: 2018-12, PKN, Warszawa 2018. 


\section{ISO 20400 jako przykład systemowego podejścia do zrównoważonego rozwoju w zakupach}

Wytyczne ISO 20400: 2017 dotyczące zrównoważonych zakupów to kolejna po ISO 26000 propozycja Międzynarodowej Organizacji Normalizacyjnej dla organizacji chcących realizować założenia zrównoważonego rozwoju i społecznej odpowiedzialności w swoich procesach. Zagadnienie zrównoważonych zakupów nie jest nowe. Już od wielu lat w Unii Europejskiej stosowane są wytyczne dla zrównoważonych zakupów publicznych (sustainable public procurement) czy zielonych zakupów publicznych (green public procurement), a kraje partnerskie mają w swoich regulacjach odpowiednie przepisy je uwzględniające ${ }^{26}$. Najnowsza propozycja nie ogranicza się jednak do procesu realizowanego przez podmioty publiczne, ale jest dokumentem uniwersalnym - do zastosowania w organizacji z każdego sektora, bez względu na jej wielkość i specyfikę działania.

Zrównoważone zakupy to „zakupy, które mają największy możliwy pozytywny wpływ o charakterze środowiskowym, społecznym i gospodarczym przez cały cykl życia" 27 . W praktyce chodzi o sposób nabywania dóbr, w którym minimalizowany jest negatywny wpływ na środowisko i społeczeństwo. Dotyczy to zarówno samego procesu, jak i produktów.

Wytyczne nie podlegają certyfikacji, są jedynie przewodnikiem po wypracowanych zasadach, polityce i strategii dla zrównoważonych zakupów. Organizacje, które zdecydują się na włączenie zrównoważonego rozwoju do swoich strategii zakupowych, mają za zadanie zintegrować go ze wszystkimi praktykami zakupowymi. Integracja wymaga spojrzenia na stronę kosztową oraz możliwości wypracowania innowacyjnych rozwiązań. Analiza kosztów dla całego cyklu życia pozwoli ocenić zakres wydatków niezbędnych do wdrożenia danych usprawnień, oceni sensowność planowanych rozwiązań oraz zderzy je z potencjalnymi korzyściami ekonomicznymi, społecznymi i środowiskowymi. Pozwoli również oszacować, czy proponowane innowacyjne rozwiązania dla praktyk zakupowych, przyczyniające się do osiągania celów zrównoważonego rozwoju, są opłacalne. Sama organizacja powinna zmienić swoje podejście do zakupów i nabywać wyłącznie to, co jest potrzebne i ma parametry spełniające kryteria społeczne i środowiskowe. Ważne jest również to, aby organizacja zwracała uwagę na przejrzystość swoich decyzji i działań w obszarze zakupów oraz na to, aby dostawcy, z którymi współpracuje, dbali o przejrzystość swoich zachowań.

26 Green and Sustainable Public Procurement, https://ec.europa.eu/environment/gpp/versus _en.htm (dostęp: 5.02.2020).

27 Za ISO 20400: 2017. 
Do innych zasad zrównoważonych zakupów należą:

- branie odpowiedzialności za wpływ, jaki organizacja wywiera na różnych interesariuszy, w tym w łańcuchu dostaw, z uwzględnieniem całego życia towarów i usług,

- etyczne postępowanie w organizacji i łańcuchu dostaw,

- zapewnienie pełnych i uczciwych szans konkurowania dla dostawców,

- poszanowanie interesów interesariuszy oraz praw człowieka,

- respektowanie prawa oraz międzynarodowych norm postępowania.

Zrównoważone zakupy to proces, w związku z czym trzeba zadbać o to, aby jego realizacja odbywała się w myśl zasady ciągłego doskonalenia praktyk i wyników, $\mathrm{w}$ tym $\mathrm{z}$ uwzględnieniem łańcucha dostaw ${ }^{28}$.

Dla zrównoważonych zakupów szczególnie istotne są następujące obszary ${ }^{29}$ :

- ład organizacyjny: procesy podejmowania decyzji i struktura procesu decyzyjnego,

- prawa człowieka,

- prawa pracy,

- ochrona środowiska,

- uczciwe praktyki operacyjne,

- zagadnienia konsumenckie,

- zaangażowanie społeczne i rozwój społeczności lokalnej.

Powyższe obszary pokazują złożoność procesu. Chcąc wybrać dostawcę, organizacja powinna wyznaczyć kryteria wyboru dla samego podmiotu (np. brak pracy dzieci, przestrzeganie prawa pracy, działania na rzecz środowiska) i nabywanego dobra (np. materiały ekologiczne, alternatywne opakowania). W wielu przypadkach wymaga to redefiniowania celów i polityki zakupowej.

Organizacje muszą podjąć się zadania zweryfikowania swoich dotychczasowych praktyk zakupowych oraz oceny procesów realizowanych w łańcuchach dostaw pod kątem ryzyka i szans, jakie daje reorientacja na zrównoważony rozwój. Pozwoli to na określenie priorytetów i wyznaczenie celów adekwatnych do organizacji, jej możliwości i aktualnych potrzeb. Uwzględnienie zrównoważonego rozwoju w procesie zakupowym powinno być widoczne w opracowanej strategii. 


\section{Podsumowanie}

Proces zakupów stanowi kluczowy element upowszechniania zrównoważonego rozwoju w łańcuchu dostaw. Będąc ogniwem łączącym dostawcę z odbiorcą, może kreować warunki dla rozwoju standardów społecznych i środowiskowych. W procesie zakupów następuje sprawdzenie, czy dostawca zdolny jest dostarczyć surowce, komponenty lub półprodukty spełniające wymagania odbiorcy. Jest to przestrzeń na określenie odpowiednich warunków brzegowych związanych z ochroną środowiska czy prawami człowieka.

Obecnie firmy poszukują dostawców, którzy współdzielą system wartości i podejście do kwestii środowiskowych i społecznych. Gwarantuje to, że współpraca będzie trwała i korzystna dla obu stron.

Zrównoważone zakupy to strategiczne podejście do procesu zaopatrzenia, mające na celu ograniczanie ryzyka oraz świadome zarządzanie wpływami społecznymi i środowiskowymi. Jest to także budowanie potencjału dla analizy procesów w całym cyklu życia produktów, co stanowi nadal wyzwanie dla wielu firm. Ustalenie kryteriów i miar oceny w procesie zakupów ułatwia egzekwowanie przyjętych standardów. Wspiera proces uczenia organizacyjnego obu stron. Konfrontuje chęci odbiorców z możliwościami dostawców i pozwala spotkać się w procesie planowania i rozwijania celów do osiągnięcia - etap po etapie w dłużej perspektywie.

Przedsiębiorstwa, które zdecydują się na transformację procesu, powinny należycie zaplanować wszystkie etapy zmiany, mając na uwadze zarówno swoje cele, jak i potrzeby oraz oczekiwania zainteresowanych stron. Wyznaczanie priorytetów, szukanie alternatyw, rezygnacja z zakupów, które nie przynoszą wartości dodanej i umiejętne poruszanie się po zagadnieniach społecznych i środowiskowych to z pewnością duże wyzwanie, zwłaszcza w początkowej fazie.

Wytyczne ISO 20400 nie są jedyną propozycją dla organizacji chcących włączyć koncepcję zrównoważonego rozwoju do zarządzania procesami logistycznymi. Do wyboru jest dużo więcej podejść i inicjatyw, które - podobnie jak omawiany dokument - wyznaczają kierunek działania organizacji. Wartością wytycznych jest zwrócenie uwagi na konkretny proces i próba przeprowadzenia zainteresowanej organizacji przez poszczególne etapy, ważne dla skutecznej jego realizacji. Zrównoważony rozwój to koncepcja, której nie da się ignorować - należy ją zrozumieć i umiejętnie przełożyć na sukces organizacji. 
Bibliografia

Boström M., Jönsson A.M., Lockie S., Mol A.P.J., Osterver P., Sustainable and responsible supply chain governance: challenges and opportunities, „Journal of Cleaner Production” 2015, no. 107, s. 1-7.

Carr A.S., Smeltzer L.R., An empirically based operational definition of strategic purchasing, „European Journal of Purchasing and Supply Management" 1997, vol. 3, no. 4, s. 199-207.

Carter J.R., Narasimhan R., Is purchasing really strategic?, „International Journal of Purchasing and Materials Management" 1996, vol. 32, no. 4, s. 20-28.

Christopher M., Ryals L., Supply chain strategy: its impact on shareholder value, „International Journal of Logistics Management" 1999, vol. 10, no. 1, s. 1-10.

Cousins P., Lamming R., Lawson B., Squire B., Strategic Supply Management. Principles, Theories and Practice, Pearson Education, Harlow 2008.

Ekologiczne zakupy! Podręcznik dotyczący zielonych zamówień publicznych, https://ec.europa.eu /environment/gpp/pdf/handbook_2016_pl.pdf (dostęp: 5.02.2020).

Flynn B.B., Huo B., Zhao X., The impact of supply chain integration on performance: a contingency and configuration approach, „, Journal of Operations Management” 2010, vol. 28, no. 1, S. 58-71.

Ghosh A., Fedorowicz J., The role of trust in supply chain governance, „Business Process Management Journal" 2008, vol. 14(4), s. 453-470.

Grant D.B., Trautrims A., Wong C.Y., Sustainable logistics and supply chain management: principles and practices for sustainable operations and management, Kogan Page Publishers, New York 2017.

Green and Sustainable Public Procurement, https://ec.europa.eu/environment/gpp/versus_en .htm (dostęp: 5.02.2020).

Klauzule społeczne i środowiskowe w zamówieniach publicznych, https://www.swietokrzyskie.pro /klauzule-spoleczne-i-srodowiskowe-w-zamowieniach-publicznych (dostęp: 5.02.2020).

Kumar D., Rahman Z., Sustainability adoption through buyer supplier relationship across supply chain: A literature review and conceptual framework, „International Strategic Management Review" 2015, vol. 3, issues 1-2, s. 110-127.

Lysons K., Farrington B., Purchasing and Supply Chain Management, Pearson Education, Harlow 2006.

Mena C., Sustainable Procurement, [w:] C. Mena, R. van Hoyek, M. Christopher, Leading procurement strategy. Driving value through the supply chain, Kogan Page, Croydon 2014, s. 171-194.

Monczka R.M., Handfield R.B., Giunipero L.C., Patterson J.L., Waters D., Purchasing and Supply Chain, Management, South-Western Cengage Learning, Andover 2010.

Nestlé oskarżone o zatrudnianie dzieci. Czy w Polsce problem też występuje?, https://www.pulshr .pl/prawo-pracy/nestl-oskarzone-o-zatrudnianie-dzieci-czy-w-polsce-problem-tez-wyst epuje,30942.html (dostęp: 5.02.2020).

Norma ISO 20400: 2017 Sustainable Procurement - Guidance.

Ocicka B., Rola zakupów w działalności przedsiębiorstw, Wydawnictwo Naukowe PWN, Warszawa 2019.

Quariguasi Frota Neto J., Bloemhof-Ruwaard J.M., Nunen J.A.E.E. van, Heck E. van, Designing and evaluating sustainable logistics networks, „International Journal of Production Economics" 2008, vol. 111, issue 2, s. 195-208.

Rudnicka A., Codes of conduct and codes of ethics as tools used to support the idea of social responsibility in supply chains, „Prace Naukowe Uniwersytetu Ekonomicznego we Wroctawiu" 2017, nr 464, s. 91-100. 
Rutkowski K., Zakupy w biznesie - potrzeba strategicznej reorientacji, „Kwartalnik Nauk o Przedsiębiorstwie" 2013, nr 4, s. 35-45.

Śmierć dzieci w kopalniach kobaltu. Pozwane Apple, Google, Dell i Tesla, https://www.national -geographic.pl/aktualnosci/smierc-dzieci-w-kopalniach-kobaltu-pozwy-dla-apple-goog le-dell-i-tesla (dostęp: 5.02.2020).

Tchokogue A., Nollet J., Robineau J., Supply's strategic contribution: An empirical reality, „Journal of Purchasing and Supply Chain Management” 2017, vol. 23, issue 2, s. 105-122.

Ustawa z dnia 23 kwietnia 1964 r. - Kodeks cywilny (Dz.U. z 1964 r. Nr 16, poz. 93 z późn. zm.).

Watts Ch.A., Kim K.Y., Hahn Ch.K., Linking Purchasing to Corporate Competitive Strategy, „International Journal of Purchasing and Materials Management" 1992, vol. 31, issue 1, s. 2-8.

Weele A.J. van, Purchasing and Supply Chain Management. Analysis, Strategy, Planning and Practice, Cengage Learning, Andover 2010.

\section{Streszczenie}

Celem artykułu było przybliżenie problematyki zrównoważonego rozwoju w procesie zakupów. Przedsiębiorstwa coraz częściej poszukują rozwiązań, które pozwolą im na godzenie interesów biznesowych z oczekiwaniami społecznymi i zmieniającymi się przepisami. Proces zakupów jest kluczowy dla realizacji celów biznesowych. Włączenie zagadnień społecznych i środowiskowych na etapie strategii zakupowej pozwala na bardziej świadome zarządzanie wyzwaniami. Organizacje mają do wyboru kilka sposobów na integrowanie zrównoważonego rozwoju. Jednym z nich są wytyczne ISO 20400 poświęcone w całości zrównoważonym zakupom. Dokument ten pozwala przejść przez obszary priorytetowe dla procesu i ułatwia zrozumienie istoty aspektów społecznych i środowiskowych w zakupach. Niniejszy artykuł ma charakter przeglądowy. Przedstawiono w nim podejście oparte na uniwersalnych wytycznych międzynarodowych.

Słowa kluczowe: zakupy, zrównoważony rozwój, ISO 20400, proces zakupowy, łańcuch dostaw

\section{Business purchasing focused on sustainable development. The role of ISO 20400 standard}

\section{Abstract}

The aim of the paper was to present the issues of sustainable development in the purchasing process. Enterprises are increasingly looking for solutions that will allow them to reconcile business interests with social expectations and changing regulations. The purchasing process is key to achieving business goals. The inclusion of social and environmental issues at the purchasing strategy stage allows to manage challenges comprehensively. Organizations have several ways to integrate sustainable development. One of them is the ISO 20400 guidelines devoted entirely to sustainable purchasing. The document allows to go through priority areas for the process and facilitates the understanding of the essence of social and environmental aspects of purchasing. It presents an approach based on universal international guidelines.

Keywords: purchasing, sustainable development, ISO 20400, purchasing process, supply chain 